\title{
Hukommelsesklinikk - poliklinisk utredning ved mistanke om demenssykdom
}

\author{
Pasientene som utredes ved Hukommelsesklinikken ved Oslo universitetssykehus er unge, halvparten \\ er under 65 år. De fleste har mild kognitiv svikt eller demenssykdom i svært tidlig fase, andre kommer for \\ en annenhåndsvurdering. Utredningen tar 2-3 timer og utføres av lege og sykepleier. Den omfatter klinisk \\ unders $\emptyset$ kelse, kognitiv testing, MR-undersøkelse med måling av mediale temporallapp, spinalpunksjon \\ og enfotonstomografi (SPECT av hjernen).
}

\section{Anne Brækhus}

anne.braekhus@ous-hf.no

Nevrologisk avdeling

og

Geriatrisk avdeling

Ingun Ulstein

Nasjonalt kompetansesenter for aldring og helse Geriatrisk avdeling

\section{Torgeir Bruun Wyller}

Geriatrisk avdeling

Knut Engedal

Nasjonalt kompetansesenter for aldring og helse Geriatrisk avdeling

Oslo universitetssykehus, Ullevål

Ifølge epidemiologiske studier har ca. 70000 nordmenn en demenssykdom. I 2040 kan antallet bli det dobbelte fordi demens i hovedsak forårsakes av aldersrelaterte hjernesykdommer (1). Mange personer med demens er ikke utredet og har ikke fått noen diagnose (2). Mer enn $95 \%$ av de rammede er over 65 år, og den største andelen har demens av Alzheimers type, vaskulær demens eller en kombinasjon av disse (3). Personer som er rammet av andre, primært nevrologiske, sykdommer vil ofte utvikle kognitiv reduksjon/demens som en del av sykdomsbildet. Det gjelder for eksempel ved Parkinsons sykdom, Parkinson pluss-sykdommer, lewylegemesykdom, amyotrofisk lateral sklerose (ALS) eller multippel sklerose (4-6).

Demens utvikles vanligvis langsomt. I et tidlig stadium kan det være vanskelig å skille personer som opplever redusert hukommelse eller mild kognitiv svikt som ikke utvikler seg til demens fra personer med en begynnende demenssykdom. Kognitiv reduksjon som ofte ikke utvikler seg videre til demens, kan for eksempel ses ved svikt relatert til hjerneslag og ved moderat til alvorlig depresjon. Av dem som fyller diagnosekriteriene for mild kognitiv svikt vil $10-15 \%$ årlig utvikle en demens- sykdom, i første rekke demens av Alzheimers type (7).

I 1990 ble det etablert en hukommelsesklinikk ved Geriatrisk avdeling, Ullevål sykehus. Hovedformålet var å etablere en enkel, standardisert og lite tidkrevende undersøkelse for diagnostikk av eldre der det var mistanke om demens eller kognitiv svikt av annen årsak (8). Før 1990 var det vanlig at pasienter med mistenkt demens ble innlagt $i$ en døgnpost til observasjon i 3-4 uker. Tilbudet «hukommelsesklinikk» var etterspurt, og i løpet av kort tid var det venteliste på over et halvt år.

Siden Hukommelsesklinikken ble opprettet har utredningsprosedyren blitt betydelig endret, tilpasset forandringen i pasientene som henvises. Primærhelsetjenesten, geriatriske og alderspsykiatriske poliklinikker har overtatt utredningen av «gårsdagens» hukommelsesklinikkpasienter, det vil si pasienter med åpenbar kognitiv svikt og endret atferd, mens Hukommelseskli-

\section{«Antall personer som} utvikler symptomer forenlig med en demenssykdom vil øke betydelig i årene fremover»

nikken på Ullevål tar imot yngre pasienter og pasienter med vage symptomer som kan indikere demens, men som ikke nødvendigvis er det.

I denne artikkelen beskriver vi hvordan Hukommelsesklinikken er organisert og de metodene som anvendes, som et eksempel på hvordan en moderne hukommelsesklinikk bør fungere. Vi beskriver to typiske pasienter og presenterer tanker om nye tiltak og tilbud som bør iverksettes av poliklinikken.
Pasient 1. En kvinne i begynnelsen av 60årene hadde hatt redusert hukommelse i et par år og flere episoder av dager til ukers varighet med forvirret og aggressiv atferd. Utredning med MR-undersøkelse ved annen avdeling viste rommelige sulci. Spinalvæskeundersøkelse påviste celler på $11 \cdot 106 / l$ (referanseverdi $<4 \cdot 10^{6} / \mathrm{l}$ ), betaamyloid 360 ng/l (referanseverdi > $550 \mathrm{ng} / \mathrm{l}$ ) og normale verdier for tauprotein og fosforylert tau. Nevropsykologisk undersøkelse viste lette til moderate vansker innen oppmerksomhet, hukommelse og problemløsning. Hun fikk diagnosen demens av Alzheimers type.

Hun ble henvist til Hukommelsesklinikken for en annehåndsvurdering. Ektefellen fortalte om redusert hukommelse, mindre initiativ og psykomotorisk treghet. Etter hvert utviklet hun fin generell tremor, postural tremor (mest uttalt i venstre side) og bilateral intensjonstremor. Hun hadde nedsatt medsving høyre arm ved gange, men for øvig var gangen upåfallende. Hun skåret 29 av 30 poeng på Mini Mental Status-evaluering (MMSE), mens resultatet på Trail Making Test $A$ og $B$ lå mellom 1 og 2 standardavvik under aldersgjennomsnittet.

På grunn av litt uvanlig sykehistorie, celler i spinalvæsken, SR på 40 og lett forhøyet ANA vurderte vi om det kunne foreligge vaskulitt, men MR-undersøkelse av hjernen med angiografi ble beskrevet som normal.

Hun fikk også kramper i underekstremitetene om natten, men de forsvant ved seponering av donepezil. Etter hvert oppsto tiltakende tremor samt søvnproblemer. Det ble utført DaT-skann lenfotonstomografi for fremstilling av basalgangliene), som viste nedsatt aktivitet i striatum bilateralt, muligens med litt mer affeksjon av putamen på høyre side enn på venstre. På bakgrunn av kognitiv reduksjon forenlig med demens, funnene ved DaT-skann samt REM-søvnfaseforstyrrelse anser vi demens med lewylegemer som mest sannsynlig (9).

Pasient 2. En kvinne i 40-årene med type 2diabetes hadde hatt subjektivt redusert 
hukommelse i omtrent to år. Utredning ved lokalsykehus viste redusert kognitiv funksjon på flere områder. Det var normale funn ved $M R$ av hjernen og i spinalvæsken, og man antok at sannsynligheten for demenssykdom var liten. Muligheten for psykiatrisk sykdom ble vurdert.

Utredning ved Hukommelsesklinikken påviste redusert verbal hukommelse og ordproduksjon. MR av hjernen med måling av temporallappene viste temporallappsatrofi grad 0 på høyre side, grad 2 på venstre side (visuell skala fra 0 til 4, der 0 er ingen atrofi og 4 er uttalt atrofi). Genetisk undersøkelse viste at hun hadde ApoE-genotypen E3/E3.

Ny samtale med pasienten et år senere bar preg av ordfinningsproblemer. Kognitiv testing viste ikke uttalte hukommelsesproblemer, men pasienten selv oppfattet plagene som mest relatert til redusert hukommelse. Diagnosen ble vurdert som mest forenlig med primær progredierende afasi, som er en variant av frontotemporallappsdemens (10). Det var normale funn ved enfotonstomografi og positronemisjonstomografi (PET).

\section{Organisering av Hukommelsesklinikken}

Personalressursene består av 3,5 legeårsverk, tre sykepleierårsverk og en sekretær. Legene, som er spesialister i enten geriatri, nevrologi eller psykiatri, utfører den initiale kognitive testingen samt somatisk, nevrologisk og psykiatrisk undersøkelse, avhengig av symptomene. Ved å ha ansatt leger med de tre spesialitetene innehar vi den kompetansen som vanligvis er nødvendig for utredning av pasientgruppen. Sykepleierne har spesialutdanning i enten geriatri eller psykiatri.

En basiskonsultasjon tar omtrent to timer pluss journalskriving. Lege og sykepleier samarbeider om utredningen. For enkelte supplerende undersøkelser, først og fremst spinalpunksjon, må pasientene komme tilbake til ny undersøkelse.

\section{Undersøkelsens innhold}

Sykehistorie og komparentinformasjon Et viktig element $i$ utredningen er å innhente sykehistorie fra en pårørende uten at pasienten er til stede. Vi får ofte tilbakemelding fra pårørende om at de hos andre leger ikke har fått slippe til alene. Av hensyn til pasienten har de derfor ikke klart eller ønsket å gi uttrykk for hvor uttalte symptomene er.

Mens pasienten vurderes av lege, fyller pårørende ut ulike skjemaer (fig 1) i nært samarbeid med sykepleier. Skjemaene danner grunnlaget for legens intervju med pårørende. Siden problemområder allerede er identifisert i samtalen med sykepleier, kan tiden hos lege kortes ned betraktelig ved at det umiddelbart kan settes søkelys på de områdene som har mest betydning for differensialdiagnoser og psykososiale tiltak.

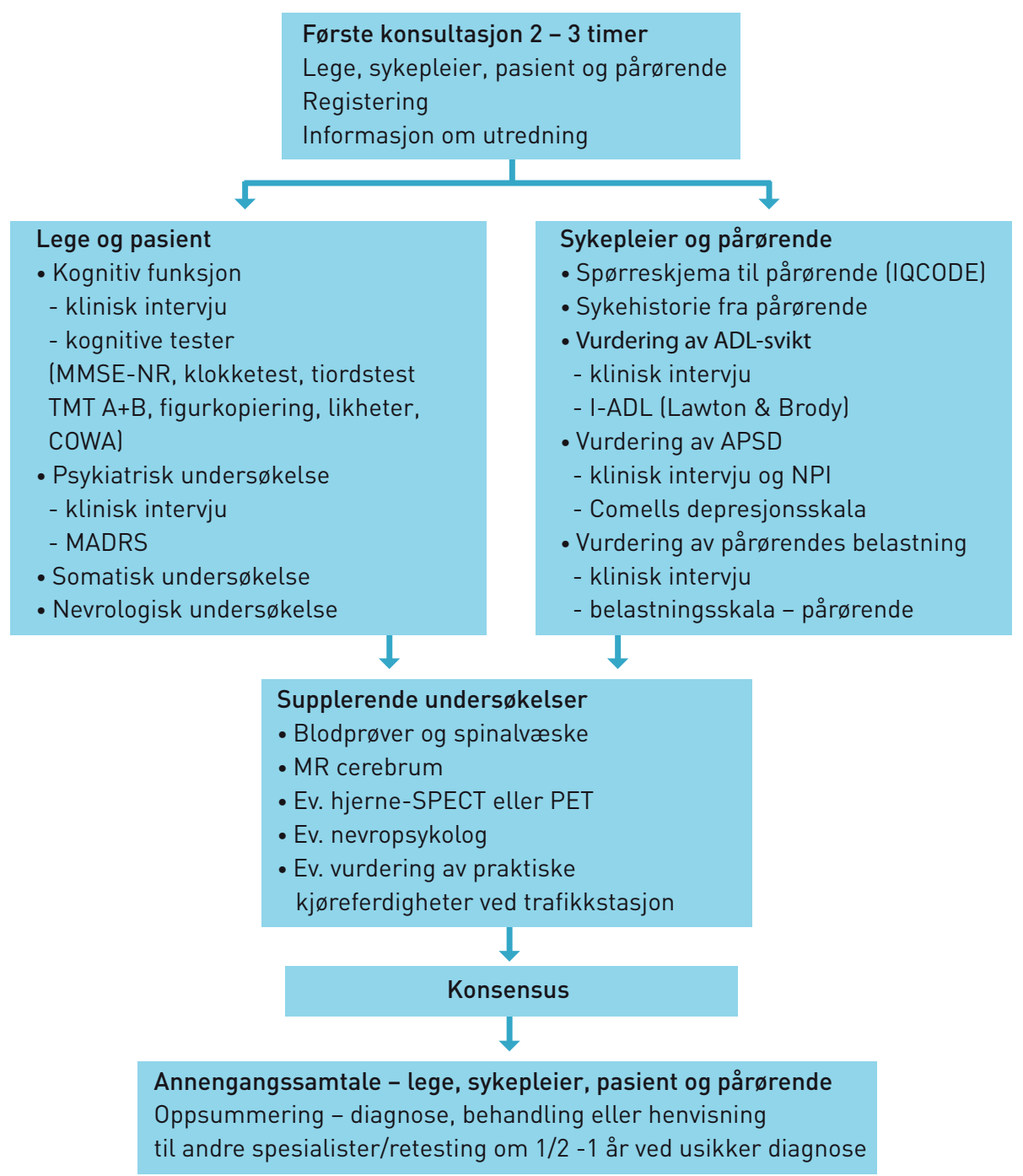

Figur 1 Prosedyre for utredning ved Hukommelsesklinikken. Forklaringer: MMSE-NR = Norsk revidert Mini Mental Status-evaluering, TMT A og B = Trail Making Test A og B, COWA = Controlled Oral Word Association, MADRS = Montgomery-Åsberg Depression Rating Scale, IQCODE = Informant Questionnaire for Cognitive Decline, $A D L=$ Activities of Daily Living, I-ADL = Instrumentell ADL, APSD = atferdsmessige og psykologiske (psykiatriske) symptomer ved demens, NPI = nevropsykiatrisk intervjuguide

\section{Undersøkelse av pasienten}

Vurdering og testing av kognitiv funksjon, somatisk status inkludert orienterende nevrologisk undersøkelse og en psykiatrisk vurdering med vekt på komorbid depresjon utgjør grunnsteinene i vurderingen. Figur 1 viser de viktigste kognitive testene som benyttes rutinemessig. Hos noen pasienter gjøres utvidet testing hos lege eller nevropsykolog, avhengig av problemstillingen.

\section{Strukturelle og funksjonelle} hjerneundersøkelser

Flere studier har vist atrofi i entorhinal cortex og hippocampus hos pasienter med demens av Alzheimers type (11). MR cerebrum med vurdering av medial temporallappsatrofi utføres derfor hos alle. Enfotonstomografi og positronemisjonstomografi (FDG-PET) rekvireres hos noen pasienter, avhengig av problemstillingen (12). Ved mistanke om frontotemporal- lappsdemens gjøres alltid enfotonstomografi. Ved spørsmål om demens med lewylegemer eller en Parkinson pluss-sykdom rekvireres enfotonstomografi med $1231 \mathrm{FP}-$ CIT (DaT-skann). Denne undersøkelsen bidro til avklaring hos pasient 1 .

\section{Spinalvæskeundersøkelser}

Fra 2008 gjøres spinalpunksjon hos en stor andel av pasientene, dels i differensialdiagnostisk øyemed (celler, protein, glukose, proteinelektroforese og borrelia), dels for analyse av «demensmarkørene» betaamyloid, totalt tau og fosforylert tau (13).

\section{Diagnostikk}

Diagnosen stilles i henhold til diagnosekriteriene ICD-10. Diagnoser som ikke er beskrevet i ICD-10, stilles i henhold til internasjonale konsensuskriterier, som Manchester-Lund-kriteriene for frontotemporallappsdemens (10) og McKeith-krite- 
riene for demens med lewylegemer (14). Diagnosene settes etter diskusjon i ukentlige konsensusmøter der psykiater, geriater og nevrolog deltar. I 2007 ble det foreslått nye kriterier for demens av Alzheimers type som krever at det foreligger redusert episodisk hukommelsesfunksjon samt enten medial temporallappsatrofi på MR av hjernen, forandringer i en eller flere av spinalvæskemarkørene, typiske forandringer på PET eller en genetisk mutasjon. Disse kriteriene er imidlertid foreløpig beregnet på forskning (15) og benyttes ikke i vår kliniske hverdag.

Pasient 2 hadde ved symptomdebut subjektive symptomer samt funn ved nevropsykologisk undersøkelse, men normale funn ved MR av hjernen og spinalpunksjon. Kasuistikken illustrerer hvor viktig det er å legge avgjørende vekt på sykehistorie og kliniske funn og ikke på supplerende undersøkelser.

\section{Førerkortvurdering}

En viktig del av arbeidet ved poliklinikken er vurdering av skikkethet for førerkort. Pasientene vurderes med det standardiserte undersøkelsesbatteriet, noen henvises til testing hos nevropsykolog og mange henvises til vurdering av praktiske kjøreferdigheter ved Oslo trafikkstasjon. Pårørende intervjues, og den endelige avgjørelsen tas på bakgrunn av all tilgjengelig informasjon.

\section{Behandling}

Behandlingen som tilbys, omfatter både medikamentelle og ikke-medikamentelle tiltak. Det medikamentelle tilbudet er enten behandling med kolinesterasehemmere eller memantin ved demens av Alzheimers type. Dersom vi påviser tydelige tegn til depressiv sykdom eller betydelige depressive symptomer, initierer vi eller anbefaler fastlege å starte antidepressiv behandling før antidemensbehandling igangsettes.

Når det gjelder ikke-medikamentelle tilbud, gis det omfattende informasjon til pasient og pårørende. Det omfatter også skriftlige informasjonsbrosjyrer. Henvisninger til hjemmebaserte tjenester sendes dersom dette ikke allerede er gjort av primærhelsetjenesten. I tillegg tilbys samtalegrupper for pasienter og pårørende.

\section{Klinisk virksomhet}

I 2010 ble 907 pasienter vurdert - 259 førstegangsundersøkelser, 162 pasienter kom til revurdering av diagnosen 6-12 måneder etter den initiale undersøkelsen og 486 pasienter kom til kontroll i forbindelse med ulike former for behandling. Ventetiden varierer mellom 12 og 14 uker. I alt 134 av pasientene (49\%) som kom til første gangs undersøkelse var under 65 år. Mild kognitiv svikt var den vanligste diagnosen og ble stilt hos $32 \%, 27 \%$ fikk diagnosen subjektiv redusert hukommelse, mens $21 \%$ fikk diagnosen demens av Alzheimers type.
Resten fordelte seg på andre typer demens samt depressive tilstander.

\section{Demensregister}

I tillegg til flere egne forskningsprosjekter bidrar Hukommelsesklinikken til et stort regionalt register av pasienter som utredes ved mistanke om demens. For å gjøre demensutredningen i Norge bedre og mer harmonisk, ble det i 2009 etablert en undersøkelsesprotokoll og database der poliklinikker i Helse Sør-Øst som utreder pasienter med demens ble invitert til å delta. Nasjonalt kompetansesenter for aldring og helse er ansvarlig for registeret. Registeret utvides stadig med flere poliklinikker både fra Helse Sør-Øst og Helse Vest og omfatter nå 15 poliklinikker. Biologisk materiale (blod, spinalvæske, urin og spytt) lagres i en forskningsbiobank. Fordelen med deltakelse i dette registeret er at det i løpet av relativt kort tid samles inn mye data, noe som muliggjør raskere evaluering av nytteverdien av de diagnostiske verktøyene som benyttes.

\section{Diskusjon}

Hukommelsesklinikken har vært i funksjon i 20 år. I løpet av denne tiden har utredningsmodellen gjennomgått flere endringer, ikke minst tilpasset den endringen som er skjedd i pasientpopulasjonen over tid. Mange av pasientene henvises til annenhånds- eller tredjehåndsvurdering. Vi opplever at etterspørselen er stor.

Faktorer som kan forklare modellens levedyktighet er fortløpende tilpasninger av undersøkelsesbatteriet og involvering av leger med ulike spesialiteter. Medvirkning av psykiater, nevrolog og geriater er nødvendig, siden demenssykdommene ligger i skjæringspunktet mellom disse spesialitetene og hver gruppe har erfaring med ulike deler av utredningen. Det er imidlertid viktig at spesialistene har kontakt med sin «moderavdeling» for å vedlikeholde egen spesialitet samt for diskusjoner rundt vanskelige problemstillinger.

Vi mener det bør avsettes god tid til første konsultasjon, slik at man kan gjennomføre praktisk talt hele utredningen. Det er avsatt tid til faste ukentlige samarbeidsmøter der mange av pasientene diskuteres.

Et annet aspekt ved vår modell er legenes aktive deltakelse i utredningsprosessen. Legene står for de fleste av vurderingene samtale, somatisk status og kognitiv testing. Dette gir et bredt grunnlag for å stille diagnosen, noe som er spesielt viktig i tidlig fase av en demenssykdom. Det kan foreligge subtile forandringer som kan være til stor bekymring for pasienten, uten at dette fanges opp ved kognitiv testing. Sykehistorien kan likevel vekke mistanke om at «noe er på gang» og pasienten kan følges over tid. I mange tilfeller vil man kunne påvise en demenssykdom flere år senere. Slike pasienter utgjør en sårbar gruppe, siden mange faller ut av arbeidslivet og er avhengig av å få en diagnose av hensyn til rettigheter i NAV-systemet.

Antall personer som utvikler symptomer forenlig med en demenssykdom vil øke betydelig $i$ årene fremover. For å kunne møte større etterspørsel kan man tenke seg en modell der alle gjennomgår en standardundersøkelse med en begrenset utredning, mens mer spesielle tester/undersøkelser benyttes der man ikke kommer til målet med standardbatteriet, for eksempel ved uvanlige symptomer, rask utvikling eller hos yngre pasienter.

Det viktig at poliklinikken til enhver tid er oppdatert og benytter gode og internasjonalt anerkjente utredningsverktøy, som for eksempel ulike MR-teknikker (16). Vi mener likevel at det fremdeles er en god sykehistorie fra en pålitelig pårørende som er det aller viktigste diagnostiske hjelpemiddel for å sette legen på sporet av riktig diagnose (17).

\section{Konklusjon}

Hukommelsesklinikken er et poliklinisk utredningstilbud ved mistanke om demenssykdom, fortrinnsvis til yngre personer eller der det foreligger et komplisert eller uvanlig sykdomsforløp. Vi mener at et tilsvarende tilbud bør etableres ved andre universitetsklinikker i Norge.

Pasientene har gitt tillatelse til at artikkelen blir publisert.

Anne Brækhus (f. 1961)

er dr.med. og spesialist i nevrologi og overlege på Geriatrisk avdeling, Hukommelsesklinikken og på Nevrologisk avdeling, Oslo universitetssykehus, Ullevål.

Ingen oppgitte interessekonflikter.

\section{Ingun Dina Ulstein (f. 1950)}

er ph.d., psykiater og ansatt som forsker ved Nasjonalt kompetansesenter for aldring og helse, Psykiatrien i Vestfold og ved Oslo universitetssykehus, Ullevål. Hun har en bistilling som overlege ved Hukommelsesklinikken, Oslo universitetssykehus

Ingen oppgitte interessekonflikter.

\section{Torgeir Bruun Wyller (f. 1960)}

er dr.med., spesialist i indremedisin og i geriatri, professor ved Universitetet i Oslo og overlege ved Oslo universitetssykehus. Oppgitte interessekonflikter: Forfatteren har mottatt honorar for foredrag om geriatriske emner fra Pfizer, Roche, AstraZeneca og Nycomed.

\section{Knut Engedal (f. 1946)}

er professor dr.med., fag-og forskningssjef ved Nasjonalt kompetansesenter for aldring og helse, Geriatrisk avdeling, Oslo universitetssykehus, Ullevål, og professor i psykogeriatri ved Universitetet i Oslo.

Ingen oppgitte interessekonflikter. 


\section{Litteratur}

1. Demensplan 2015. www.helsedirektoratet.no/ helse_omsorg/omsorgsplan_2015/ medisinsk_oppf_lging/demensplan_2015_624194 (22.6.2011)

2. Lystrup LS, Lillesveen B, Nygård AM et al. Omsorgstilbud til hjemmeboende personer med demens. Tidsskr Nor Lægeforen 2006; 126: 1917-20.

3. Ott A, Breteler MM, van Harskamp F et al. Incidence and risk of dementia. The Rotterdam Study. Am J Epidemiol 1998; 147: 574-80

4. Aarsland D, Kurz MW. The epidemiology of dementia associated with Parkinson's disease. Brain Pathol 2010; 20: 633-9

5. Giordana MT, Ferrero P, Grifoni S et al. Dementia and cognitive impairment in amyotrophic lateral sclerosis: a review. Neurol Sci 2011; 32: 9-16.

6. Smestad C, Sandvik L, Landrø NI et al. Cognitive impairment after three decades of multiple sclerosis. Eur J Neurol 2010; 17: 499-505.

7. Petersen RC, Roberts RO, Knopman DS et al. Mild cognitive impairment: ten years later. Arch Neurol 2009: 66: 1447-55

8. Oksengård AR, Braekhus A, Engedal $K$ et al. Hukommelsesklinikk - poliklinisk utredning ved mistanke om demens. Tidsskr Nor Lægeforen 1997: 117: 3678-80.

9. Mollenhauer B, Förstl H, Deuschl $G$ et al. Lewy body and parkinsonian dementia: common, but often misdiagnosed conditions. Dtsch Arztebl Int 2010; 107: 684-91

10. Neary D, Snowden JS, Gustafson L et al. Frontotemporal lobar degeneration: a consensus on clinical diagnostic criteria. Neurology 1998; 51 : $1546-54$.

11. Duara R, Loewenstein DA, Potter E et al. Medial temporal lobe atrophy on MRI scans and the diagnosis of Alzheimer disease. Neurology 2008; 71 : 1986-92.

12. Coleman RE. Positron emission tomography diagnosis of Alzheimer's disease. Neuroimaging Clin N Am 2005; 15: 837-46.

13. Blennow K, Zetterberg H. Cerebrospinal fluid biomarkers for Alzheimer's disease. J Alzheimers Dis 2009: 18: 413-7.

14. McKeith IG, Dickson DW, Lowe J et al. Diagnosis and managment of dementia with Lewy bodies: third report of the DLB concortium. Neurology 2005; 65: 1863-72.

15. Dubois B, Feldman HH, Jacova C et al. Research criteria for the diagnosis of Alzheimer's disease: revising the NINCDS-ADRDA criteria. Lancet Neurol 2007; 6: 734-46.

16. Borghesani PR, DeMers SM, Manchanda V et al. Neuroimaging in the clinical diagnosis of dementia: observations from a memory disorders clinic. J Am Geriatr Soc 2010; 58: 1453-8.

17. McKhann GM, Knopman DS, Chertkow $\mathrm{H}$ et al. The diagnosis of dementia due to Alzheimer's disease: recommendations from the National Institute on Aging-Alzheimer's Association workgroups on diagnostic guidelines for Alzheimer's disease. Alzheimers Dement 2011: 7: 263-9.

Mottatt 1.7. 2011, første revisjon innsendt 23.10 2011, godkjent 27.10. 2011. Medisinsk redaktør Erlend T. Aasheim. 